UDC 811'11'37

DOI 10.35433/philology.1(89).2019.19-24

T. V. Kolisnychenko,

PhD (Germanic Languages), Assistant Professor,

(Yuriy Fedkovych Chernivtsi National University)

t.kolisnichenko@chnu.edu.ua

ORCID: 0000-0001-5312-0522

\title{
THE CORRELATION OF EVALUATIVE AND EMOTIONAL COMPONENTS IN THE SEMANTICS OF "SETTLEMENT" NOMINATIONS
}

Our investigation is focused on the correlation of evaluative and emotional components in the semantics of tourism advertising discourse. A complex analysis including definitional, componential, discourse and corpus ones is elaborated to study the semantic structure of the tourism advertising discourse.

Scholars of different schools I. Ling (2008), R. W. Hallett (2010), C. Thurlow (2010), A. Jaworski (2010),

H. I. Panchenko (2011), L. D. Bozhko (2012), L. Y. Hovorunova (2013), N. V. Filatova (2014),

$V$. V. Mykhailenko (2015) focus on various issues of tourism advertising discourse. TAD is a special type of discourse where verbal and nonverbal means aimed at persuading clients to buy the tourism products and services.

The objective of our investigation is to define the role of the evaluation component in the lexical meaning of place names functioning settlement" nominations in the TAD printed matters, for instance, advertisements, brochures, commercials, etc.

To attract clients' attention, to convince them to choose the very company the use of and to praise them of their right choice can be achieved by the intensifiers. Intensifiers viewed as semantically insignificant words where emotional meaning dominates over semantic one. Lexical intensifiers are focused on the strengthening of the meaning of the lexeme they combine with in discourse and partly lose own semantic meaning.

The discourse register causes a shift of the meaning component in the lexical meaning of "settlement" nominations: original negative $\rightarrow$ neutral in the geographical discourse $\rightarrow$ positive in the TAD.

Key words: intensifiers, oikonym, evaluative component, semantic structure, semantic meaning, tourism advertising discourse.

Introduction. When the lexeme is used to name the place it acquires a geographical name (toponym), and all toponymic features to become a distinctive marker of the geographical object it names (river, forest, town, village, town, etc.).

The topicality of the present research is motivated by the necessity to reveal the shifts in the lexical meaning in the process of the transition from a general name to a toponymic one in non-professional and professionaloriented discourse registers. The problem of neutralizing the pejorative component in the semantics of oikonyms in the tourism advertising discourse (hereinafter TAD) has not been systematically analysed yet. Our attention is drawn to the issue of neutralizing the pejorative component of oikonym in the geographical discourse and actualizing the positive emotional components in the place name semantics when used in TAD.

The paradigm of methods for investigation includes definitional and componential analyses to reveal the semantic structure of the "settlement" nominations; etymological - to study of the origin of place names and evolution of their form and meaning in the English language; distributional analysis - to study the interrelations of oikonyms and intensifiers in the sentence pattern; discourse-analysis to prove our hypotheses that TAD neutralizes pejorative components, actualizes emotional component, and reveals a semantic shift in the oikonym lexical meaning; corpus-analysis helps to make comparisons at a large scale, reveal covert components in oikonym lexical meaning and study the shifts of perception of the place name by recipients due to the discourse registers: "exterior form" - "neutral" oikonym - "semantically positive" place name.

The data for the investigation is retrieved from the etymological dictionary [1], "Dictionary of British Place Names" by A. D. Mills [2].

Discussion. Oikonyms form a significant subsystem in the English vocabulary and present a branch of toponymy (place name) in the system of onomastics. Onomastics is a branch of linguistics that studies the personal names, cf.: onomastics (Greek onomasia "name") is the science of process of naming, otherwise it is called the theory of nomination. Onomastics as a branch of semantics studies the etymology of institutionalized ("proper") names, such as the names of people ("anthroponymy" or "anthroponomastics") and places ("toponymy" or "toponomastics"); also called onomatology. In a looser usage, "onomastics" is used for personal names and "toponymy" for place names.

Toponym comes from Greek topos "place" and -onym "name". And toponymy is the "study of place names" is from $1876[1]$.

Toponymy, taxonomic study of place-names, based on etymological, historical, and geographical information. A place-name is a word or words used to indicate, denote, or identify a geographic locality such as 
a town, river, or mountain. Toponymy divides place-names into two broad categories: habitation names and feature names. A habitation name denotes a locality that is peopled or inhabited, such as a homestead, village, or town, and usually dates from the locality's inception. Feature names refer to natural or physical features of the landscape and are subdivided into hydronyms (water features), oronyms (relief features), and places of natural vegetation growth (meadows, glades, groves).

Toponymy is concerned with the linguistic evolution (etymology) of place-names and the motive behind the naming of the place (historical and geographical aspects). Most toponymy, however, has concentrated on the etymological study of habitation names, often neglecting the study of feature names and the motive behind the naming of the place (ibid.).

"Dictionary of Linguistic Terms" by T. Zherebilo defines the toponym as a geographical name of particular territory, while oikonymy is the branch of linguistics that studies the etymology, origin, meaning and function of place names. Toponymy is further differentiated into two main subfields: macrotoponymy - names of the natural or human-created objects and microtoponymy - individual names of the small geographic objects. Further toponyms are subgrouped into oikonyms (Greek oikos "home") - names of human settlements; hydronyms (Greek hydor "water") - names of rivers; oronyms (Greek oros "hill") - names of landforms; cosmonyms names of the alien objects, also there are speleonyms - names of caves; phitonyms - names of plants; dromonyms - names of passageways; urbanonyms - names of streets, squares, etc [3].

The toponymy of British place names is the focus of E. McClure (1910), A. Mawer (1922), J. Field (1980, 2005), A. Room (1983), A. D. Mills (2011), V. A. Zhuk (2015) et al. and oikonyms are the object of investigation of A. Č. Šimpraga (2013), M. Vakulych (2013), E. M. Tkachenko (2013), G. Bachynska (2013), B. Corre (2015), P. Kryukov (2017). They concentrate on the changes in the British place name semantics due the influence of the tongues of various tribes inhabited Britain and conquerors, and study how places were named after men who obviously were important at those days to keep their names in times.

Habitation names of England are in the focus of our investigation. Our hypothesis is that there is a discourse impact causing a shift of the semantic components in the lexical meaning of oikonyms and that TAD actualizes the positive components of lexical meanings. The model of shifts has not been systemically studied yet. We have elaborated the next model of meaning shifts: $\mathrm{OM} \rightarrow \mathrm{NM} \rightarrow \mathrm{PM}$ (original meaning (negative / positive) $\rightarrow$ neutralized meaning in the geographical discourse $\rightarrow$ positive meaning in the tourism advertising discourse).

In our previous works we have investigated the peculiarities of tourism advertising discourse, primarily, its definition and characteristic features. The advertising tourism discourse can be defined as a special type of discourse (reader / consumer-oriented type) where verbal and nonverbal means are employed to add the positive component to the place name semantics aimed at "selling the place" and persuade the client to buy the tourism products. TAD is highly persuasive - it describes a reality which has to be perceived by potential tourists as authentic and which can give them an illusion of really living an "off-the-beaten-track" holiday experience [4: 1].

TAD is characterized by a network of interrelations in which both verbal and iconic elements are combined to meet the tourists' expectations (ibid.). The main functions of TAD are to arouse curiosity, to form positive pictures and values in tourist's mind and to lead tourists to self-convincing of the necessity to visit the advertised place. The main role in actualizing the emotional component to the place name (cf.: Paris (capital of fashion, romance and love) - positively charged; Palermo (the mafia's capital city) - negatively charged) belongs to evaluative components which, by V. V. Mykhaylenko, are the key marketing instrument in tourism [5]. There is no clear-cut definition of the term "evaluation", though it is a cornerstone in the framework targeted at "building and maintaining relations between writer and reader" [6: 8]. The role of evaluative component in the lexical meaning of a lexeme was in the focus of many scholars. There is a wide range of synonyms of the term "evaluative component": connotation (J. Lyons, V. V. Mykhaylenko; evidentiality (W. L. Chafe \& J. Nichols); discourse marker (B. Fraser); stance (K. Hyland); appraisal (J. R. Martin, P. R. R. White); superordinate concept (B. C. Camiciottoli); evaluation (G. Thompson, S. Hunston, M. Bednarek); modality and modalization (M. A. K. Halliday, Ch. M. I. M. Mattheissen); evaluative component (V. V. Vynogradov, L. B. Nikitina, H. I. Pryhodko, L. P. Krysin, Y. A. Sternin, I. V. Arnold). J. Lyons says that "connotation" is an additional component of the main semantic meaning of a language unit [7: 176], cf.: "evaluative component" is a part of semantic meaning of a lexeme and is included into the dictionary entry definition [8: 156]. H. I. Pryhodko suggests the opposite opinion: evaluative component expresses the common attitude of the community to the denotative meaning [9: 40]. Besides she stresses that "evaluation as language function is a tool used by speaker / writer with a particular pragmatic aim: to influence the physical and emotional state of the addressee" [9: 41].

B. C. Camiciottoli considers evaluation to be a superordinate concept [10: 53] which can be expressed by speaker/writer in a myriad of different ways and in discourse evaluation can be encoded with the help of grammatical units like adjectives, adverbs, nouns, verbs and their categories: the degrees of comparison; number; tense, aspect (ibid.: 55), paralinguistic units, e.g. intonation and nonverbal units (e.g. body languages). She sums up that evaluation is a complex phenomenon that can permeate all types of language from diverse directions (ibid.: 55). 
"A Glossary of Linguistics and Translation Studies" gives the following definition: "additional meaning which arises due to the associations a word has" [5: 122].

We support the idea expressed by V.V. Mykhaylenko that evaluation is a component of the lexeme actualized by the discourse. Evaluation plays an important role in the TAD as a marketing tool for persuading the potential consumers in the "perfectness and suitability" of a particular product and influencing them to perceive the information / things in a particular (suitable for the author) way.

Investigation. To research the role of intensifiers and evaluative components in TAD we shall analyze the functional semantics of oikonyms in three types of discourse: geographical, general and TAD.

The object of the investigation is presented by the names of famous tourist centers of England which originally had a negative component in their lexical meaning. We must admit that in the present investigation the place names for the analysis were selected randomly to demonstrate the shift in their semantics according to the "discourse environment".

Droitwich is a town (parish), in Wychavon district, an administrative and historic county of Worcestershire, in the West-Central England. The older part of the town lies along the River Salwarpe, a tributary of the River Severn; the modern Part lies on a higher ground.

In Merriam-Webster's Geographical Dictionary we find the following dictionary entry: Droitwich: town of Hereford and Worcester, W cen. England; pop. (1981p) 18.073: brine springs; health resort [11: 332].

The etymological analysis shows that name Droitwich (1086 (DB) Drihtwych) comes from the combinations of OE form wisc and OE drit "dirt" [2: 400]. OE word wīc means an earlier an Romano-British settlement; a dwelling, specialized farm or building, dairy farm; a trading or industrial settlement, a harbor (ibid.: 1174). Originally it meant a "dirty or muddy saltworks." In general discourse it is registered as a dirty place, a poor community, salt burning place:

1.1. Salt burning, on the contrary, made Droitwich one of the poorest communities in Worcestershire, almost without parallel anywhere, the township itself being' somewhat foule and dirty when any reyne faullythe, with moche carriage throwghe the stretes, being over ill pavyd or not pavyd'...Leland's gloomy view of Droitwich must have been prompted by visual symptoms - the foul streets and the sickly faces he encountered in them:' the people that be about the fornacis be very ille colorid' [12].

The text fragment reveals the original negative meaning - poorest, foul, sickly, ill-colored forming a negative, unfavorable image of the town. The Corpus-based analysis shows that the usage frequency of the given oikonym is 47 times [12]:

1.2. Are you going over to Droitwich on it or will you go in your car? I'll go to Droitwich on it, yeah. (pause) $\mathrm{Mm}$. And then coming back here to get changed or what? (pause) I've I've booked the whole morning off. Well I I p- I personally think. When you gotta go Droitwich? you would you would need...Tomorrow morning. Oh tomorrow. I personally think you would need. Well the weather forecast is dry anyway [12].

Examples 1.1 and 1.2 show that the place name loses its toponymic meaning and no emotional component is added. The place name is used just as the denotation of the place. In the geographical discourse the name of Droitwich is used as a geographical term:

1.3. Droitwich lies on the banks of the River Salwarpe on undulating ground in the central Worcestershire plain. The streets of the old town are narrow and hilly; the town conforms to no regular plan, and has no open market-place [12].

Text fragment 1.3 shows the transposition of the settlement name from the negative evaluative component to the neutrally marked. In the tourism advertising discourse the settlement name Droitwich reflects certain shift in its lexical meaning:

1.4. Welcome to the historic town of Droitwich Spa. Surrounded by the beautiful Worcestershire countryside, it is a town of great charm offering its visitors plenty of things to do, attractions and places to visit. This historic town has a great range of leisure activities available including: guided walks, an open air lido and two well maintained Green Flag parks. The Droitwich canal network (the Worcester and Birmingham canal) is a haven for walkers, cyclists and nature lovers. There are enough shops to keep retail therapists happy along with various markets that regularly take place in the town [12].

The intensifiers beautiful, historic, haven, happy create the image of 'peaceful pretty small ancient town'. The original meaning of Droitwich shifts to the peripheral position and a place name acquires additional evaluative component "gorgeous place".

TAD neutralizes the negative component in the place name semantics and actualizes the positive emotional one, so there is "a negative-to-positive" transposition in TAD.

TAD as reader-oriented discourse appeals to the reader by implementing kind and mild words, avoids negatives in description, adds additional evaluative to place-names semantics and reveals emotional components. Now we shall compare the dynamics researching several more examples.

Thurrock is a seaport and unitary authority, a geographic and historic county of Essex, England. It occupies the north bank of the Thames estuary, about 15 miles $(24 \mathrm{~km})$ east of central London. Grays is the administrative center. 
Thurrock is situated in the south of Essex and lies to the east of London on the north bank of the River Thames with an area of 165 square kilometers. It has a diverse and growing population with a population density of 976 persons per square kilometer [11].

Thurrock (Thurroce 1040-2, Thurrucca 1086 (DB)) comes from OE form thurruc. Originally applied to a stretch of marshland west of Tilbury. Original meaning is negative and Thurrock stands for "place where filthy water collects" [2: 1032].

2.1. I echo his remarks, supported by some impressive statistical evidence, about the way in which the National Health Service in Thurrock and Basildon is improving and treating more people. It is worth remembering that Basildon and Thurrock health authority now treats 11,000 more patients in hospital each year than it did when it was first created in 1982 [12].

The negative component is neutralized in the general discourse (example 2.1) and the place name is mentioned as a geographical name of settlement.

Corpus-based analysis shows the referred oikonym frequency in the BNC - 82 wordforms [12]:

2.2. The supermarket chains, Sainsbury, Tesco and Safeway have applied to the high court to try to stop the opening in this country of an American style warehouse club. Costco is due to open a club at Thurrock in Essex next month and is able to cut prices by keeping overheads low. It's classified as a wholesaler but the supermarkets say Costco should be subject to the same planning rules as retailers. This is the development that's upsetting Britain's supermarket giants. A huge warehouse that's nearing completion at Thurrock in Essex, and which offers the kind of discounts already enjoyed by millions of Americans [12].

General discourse neglects the original negative semantic meaning of the oikonym, no emotional component is added to the oikonym and the place name is used as geographic unit (example 2.2). In the geographical discourse the name of Thurrock does not actualize a negative component either:

2.3. Thurrock is situated in the south-west of Essex and borders the north bank of the Thames. Thurrock is the gateway to London with easy access to both Kent and Essex via the M25 motorway and Queen Elizabeth II Bridge, the longest cable-stayed bridge in Europe [12].

Text fragment 2.3 shows the transposition of the settlement name from the negative evaluative component "place where filthy water collects" to the neutrally marked place name.

In the tourism advertising discourse the settlement name Thurrock reflects certain shift in its lexical meaning:

2.4. Thurrock is a borough of contrasts, whether you enjoy shopping or golf, historic villages or country walks. Just a few of the hidden gems include Langdon Hills' with its remarkable views and woodland, the hidden delights of Chafford Gorges or the wonderful nature reserve at Purfleet; you can also explore the two ancient forts, have fun at Grangewaters or Grays Beach, or visit historic churches and villages [12].

Such intensifiers as remarkable, wonderful, hidden delights create the illusion of the prefect place, and the TAD neutralizes the negative meaning component of the place name and actualizes new positive emotional component the place name semantics and presents Thurrock as "great place worth visiting." To support the truth of the place name transposition we shall analyse one more place name Aldeburgh.

Aldborough, or Aldeburgh (St. Peter and St. Paul), a sea-port and parish, and formerly a representative borough and a market-town, in the union, and locally in the hundred, of Plomesgate, S. division of Suffolk, 25 miles (N. E. by E.) from Ipswich, and 94 (N. E.) from London; containing 1557 inhabitants. This place takes its name from its situation on the river Alde; it was formerly of very considerable extent and importance, possessing many valuable privileges [11]

Aldeburgh, (or Aldborough), a parish in the hundred of Plomesgate, in the county of Suffolk, 24 miles to the N.E. of Ipswich, and 94 from London. It is a seaport and municipal borough, with a separate jurisdiction. It was formerly a market town (ibid.).

The etymological analysis shows that name Aldeburgh (Aldeburc 1086 (DB)) comes from OE word (e)ald (OE old, long used) + burh (OE fortified place, stronghold), with the meaning "old or disused stronghold." The river-name Alde is a "back-formation" from the place-name [2: 74].

In the general discourse the place name Aldeburgh has neutral original meaning. Corpus-based analysis shows that the usage frequency of the oikonym in language is 149 wordforms [12]:

3.1. If classical music's more your thing, then it's worth considering the Aldeburgh Festival's Hesse Studentships. Applications for the June festivals open in the New Year, to people aged 18-25 with a real passion for classical music. Bed and breakfast accommodation in Aldeburgh is provided, together with tickets to all events; duties range from turning scores to assisting on festival walks [12].

General discourse causes the shift of the meaning from negative to neutral. In geographical discourse the transformation model (neutral-neutral) is preserved:

3.2. Aldeburgh is situated in a pleasant vale, rather below the level of high-water mark, having the river Alde on the north, and on the south the navigable river Ore, which flows from Orford to this place: it is sheltered by a steep hill, the extended summit of which forms a magnificent terrace, affording a delightful promenade, and a beautifully diversified prospect embracing the North Sea [12]. 
Example 3.2 provides the geographical information about the place name. And in such entries the pragmatic value of the name has no importance. Due to such transformation the original abstractive meaning loses its significance and the toponymic nomination moves to the dominant position.

In the tourism advertising discourse a transformation model "negative / neutral-positive" is implemented:

3.3. Aldeburgh is truly a wonderful place to visit. There's so much to see and explore! There's something for everyone and come rain, come shine Aldeburgh will keep you entertained.... Aldeburgh is a great place to indulge in some retail therapy. From well know high street favourites such as Fat Face and Jack Wills to lovely independent shops such as Tilley and Grace and Burnett \& Co. With clothes, crafts, gifts, food, home and garden shops there's something for everyone on the high street... No trip to Aldeburgh would be complete without tasting some of the famous fish and chips. Aldeburgh is the king of fish and chips, boasting three amazing shops; The Aldeburgh Fish \& Chip Shop, The Golden Galleon, and The Upper Deck. Each slightly different with their own unique character, all with the same great taste with their freshly caught fish and locally grown potatoes. 'The Times' have described Aldeburgh fish and chips as 'possibly the finest on the East Coast'. You can have them wrapped to enjoy at home or eat them the Aldeburgh way: sat on the seawall watching the waves breaking against the pebbles. Either way they're delicious [12]!

Tourism advertising discourse neutralizes the negative component in the place name semantics and due to high frequency usage of intensifiers TAD turns the negative into positive. Such intensifiers as wonderful place to visit, great place, and therapy change the perception of the place name from "boring" reality into a "must-visit" spot with "perfect" atmosphere of calmness and elegance. There is "a neutral-to-positive" transposition in TAD.

The evaluative component in the lexical meaning of the place name undergoes a transposition from negatively charges to neutralized and then to positively charged.

\section{Conclusions and Perspectives.}

1. The evaluative component in the lexical meaning of place names in tourism advertising discourse are intended to intensify the perception of the settlement in the TAD.

2. Perception of place name by recipients depends on the discourse registers: "exterior form" (geographical discourse) - neutral oikonym (general discourse) - semantically positive place name (tourism advertising discourse)

3. Lexical meaning expressed by the oikonym in the dictionary entry is fixed while in the discourse structure the evaluative component actualizes its either negative or neutral, or positive charge due to (1) the author's intention and (2) the unit valence (in the sentence structure). Accordingly, these factors facilitate the shifts in the lexical meaning of oikonyms and make the lexical meaning of the unit dynamic.

4. Perspectives of our investigation may lie in the contrastive analysis of the functional semantics of the "settlement" nominations in tourism advertising discourse and other discourse registers - fiction and newspaper - to give a systemic descriptions of the lexical meaning of the place name in the English language worldview.

\section{СПИСОК ВИКОРИСТАНИХ ДЖЕРЕЛ ТА ЛІТЕРАТУРИ}

1. Online Etymology Dictionary [Електронний ресурс] - Режим доступу до ресурсу : http://www.etymonline.com.

2. Mills D. A. Dictionary of British Place-Names / D. Mills. - NY : OUP, 2011. - 576 p.

3. Жеребило Т. В. Словарь лингвистических терминов / Т. В. Жеребило. - Назрань, 2010. - 486 с.

4. Maci S. Tourism Discourse : Professional, Promotional and Digital Voices / S. Maci. - Genova : ECIG, 2013. $356 \mathrm{p}$.

5. Mykhaylenko V. V. A Glossary of Linguistics and Translation Studies / V. V. Mykhaylenko. - Ivano-Frankivsk : King Danylo Galytskiy University of Law, 2015. - 528 p.

6. Hunston S. Evaluation in Text : Authorial Stance and the Construction of Discourse : Authorial Stance and the Construction of Discourse / S. Hunston, G. Thompson. - Oxford: OUP, 2000. - 238 p.

7. Lyons J. Semantics / J. Lyons. - Vol. 1. - Cambridge : CUP, 1977. - 897 p.

8. Крысин Л. П. Слово в современных текстах и словарях / Л. П. Крысин. - Москва : Litres, 2014. - 668 с.

9. Приходько Г. І. Оцінка і комунікація / уклад. Г. І. Приходько. - Вінниця: Нова книга, 2013. - 168 с.

10. Camiciottoli B. C. Rhetoric in Financial Discourse: A Linguistic Analysis of ICT-Mediated Disclosure Genres / B. C. Camiciottoli. - NY : Rodopy, 2013. - 212 p.

11. Merriam-Webster's Geographical Dictionary. - 3rd ed. - Springfield : Merriam-Webster, Incorporated, 2001. $1387 \mathrm{p}$.

12. Corpus of Contemporary American English [Електронний ресурс]. - Режим доступу до ресурсу: http://corpus.byu.edu/coca.

\section{REFERENCES (TRANSLATED \& TRANSLITERATED)}

1. Online Etymology Dictionary [Electronic resource]. - Online access : http: // www.etymonline.com/

2. Mills D. A Dictionary of British Place-Names / D. Mills. - NY : OUP, 2011. - 576 p.

3. Zherebilo T. V. Slovar lingvisticheskih terminov [Dictionary of Linguistic Terms] / T. V. Zherebilo. - Nazran, 2010. $-486 \mathrm{p}$.

4. Maci S. Tourism Discourse: Professional, Promotional and Digital Voices / S. Maci. - Genova : ECIG, 2013. $356 \mathrm{p}$. 
5. Mykhaylenko V. V. A Glossary of Linguistics and Translation Studies / V. V. Mykhaylenko. - Ivano-Frankivsk: King Danylo Galytskiy University of Law, 2015. - 528 p.

6. Hunston S. Evaluation in Text: Authorial Stance and the Construction of Discourse: Authorial Stance and the Construction of Discourse / S. Hunston, G. Thompson. - Oxford: OUP, 2000. -238 p.

7. Lyons J. Semantics / J. Lyons. - Vol. 1. - Cambridge : CUP, 1977. - 897 p.

8. Krysin L. P. Slovo v sovremennyh textah i slovariah [Word in Modern texts and dictionaries] / L. P. Krysin. Moscow: Litres, 2014. - 668 p.

9. Pryhodko H. I. (2003) Otzinka i komunikaziia [Evaluation and Communication]. - Vinnytsia : Nova Knyga, 2013. $-168 \mathrm{p}$.

10. Camiciottoli B. C. Rhetoric in financial discourse : A linguistic analysis of ICT-Mediated Disclosure Genres / B. C. Camiciottoli. - NY : Rodopy, 2013. -212 p.

11. Merriam-Webster's Geographical Dictionary. - 3rd ed. - Springfield : Merriam-Webster, Incorporated, 2001. $1387 \mathrm{p}$

12. Corpus of Contemporary American English [Electronic resource]. - Online access : http:// corpus.byu.edu/coca.

\section{Колисниченко Т. В. Корреляция оценочных и эмоциональных компонентов в семантике "Settlement"} номинаций.

Статья посвящена исследованию корреляции оценочных и эмоциональных компонентов в семантике

"settlement" номинаций, которые функиионируют в рекламном туристическом дискурсе английского языка. Наша гипотеза заключается в доказательстве перемещения значения в семантике "settlemеnt" номинаций и смене восприятия рециипентами ойконимов в зависимости от типа дискурса, что можно представить формулой: "первичное негативное значение" $\rightarrow$ "нейтральное значение" $\rightarrow$ "позитивное значение" в рекламном туристическом дискурсе.

Ключевые слова: интенсификаторы, ойконим, оценочный компонент, семантическая структура, семантическое значение, рекламный туристический дискурс.

\section{Колісниченко Т. В. Кореляція оцінних та емоційних компонентів у семантиці "Settlement" номінацій.}

Стаття присвячена дослідженню кореляції оцінного та емоиійного компонентів у семантиці "settlement" номінацій, які функціонують у рекламному туристичному дискурсі англійської мови. Наша гіпотеза полягає у доведенні пересуву значень в семантииі "settlement" номінацій та зміні сприймання рециипієнтами ойконімів в залежності від типу дискурсу, щзо можна представити формулою: "первинне негативне значення" $\rightarrow$ "нейтральне значення" $\rightarrow$ "позитивне значення" ойконіма у рекламному туристичному дискурсі.

Ключові слова: інтенсифікатори, ойконім, очінний компонент, семантична структура, семантичне значення, рекламний туристичний дискурс. 